\title{
ANALISIS KORELASI ANTARA KANDUNGAN FENOL TOTAL DENGAN AKTIVITAS ANTIBAKTERI EKSTRAK DAN FRAKSI Abelmoschus manihot L. TERHADAP Escherichia coli
}

\author{
Bella Jessica Magdalena Kambey ${ }^{1)}$, Sri Sudewi ${ }^{1)}$, Imam Jayanto ${ }^{1)}$ \\ ${ }^{1)}$ Program Studi Farmasi FMIPA UNSRAT Manado, 95115
}

\begin{abstract}
This study aims to determine the total phenol content and Minimum Bactericidal Concentration (MBC) and the correlation of antibacterial activity with the total phonel content of the extract and the fraction of Abemoschus manihot L. against Escherichia coli. Gallic acid was used as a comparison standard in measuring the total phenol content using a UV-Vis spectrophotometer. The total phenolic conten of gedi leaf extract and fraction from Southeast Minahasa were ethanol extract $230.23 \pm 0.008 \mu \mathrm{g} \mathrm{GAE} / \mathrm{g}, \mathrm{n}$ hexane fraction $238.37 \pm 0,024 \mu \mathrm{g} G A E / g$, ethyl acetade fraction $269.77 \pm 0.016 \mu \mathrm{g} G A E / g$, and ethanol fraction $221.51 \mu \mathrm{g} G A E / g$. The extracts and fractions were tested for antibacterial activity against E. coli by dilution method using Nutrient Broth (NB) media at concentrations of $1000 \mu \mathrm{g} /$ $\mathrm{mL}, 500 \mu \mathrm{g} / \mathrm{mL}$, and $250 \mu \mathrm{g} / \mathrm{mL}$. MBC test data (Minimum Bactericidal Concentration) were analyzed using Kolmogrov-smirnov, then continued with pearson correlation test. The result of the normality test showed that the extract and the A.manihot fraction had significantly distributed normal vlue ( $p>0.05)$. Analysis Correlation of Pearson of extracts and fraction of A. manihot with antibacterial activity against E.coli showed significant result ( $p<0.05$ ). $71 \%$ of antibacterial activity is influenced by total phenolic and the rest is contribution of other compounds that have the potential as antibacterial.
\end{abstract}

Keywords: Phenol Total, Correlation, Escherichia coli, Green Gedi

\begin{abstract}
ABSTRAK
Penelitian ini bertujuan untuk mengetahui kandungan fenol total dan Kadar Bunuh Minimum (KBM) serta korelasi aktivitas antibakteri dengan kandungan fenol total ekstrak dan fraksi Abelmoschus manihot L. terhadap Escherichia coli. Asam galat digunakan sebagai standar pembanding dalam mengukur kandungan fenol total menggunakan Spektrofotometer UV-Vis. Kandungan total fenolik pada ekstrak dan fraksi daun gedi hijau dari Minahasa Tenggara yaitu ekstrak etanol sebesar 230,23 $\pm 0,008 \mu \mathrm{g}$ GAE/g, fraksi n-heksan 238,37 $\pm 0,024 \mu \mathrm{g}$ GAE/g, fraksi etil asetat 269,77 $\pm 0,016 \mu \mathrm{g} \mathrm{GAE} / \mathrm{g}$, dan fraksi etanol $221,51 \mu \mathrm{g} \mathrm{GAE} / \mathrm{g}$. Ekstrak dan fraksi diuji aktivitas antibakteri terhadap E.coli dengan metode dilusi menggunakan media Nutrient Broth (NB) pada konsentrasi $1000 \mu \mathrm{g} / \mathrm{mL}, 500 \mu \mathrm{g} / \mathrm{mL}$, dan $250 \mu \mathrm{g} / \mathrm{mL}$. Data uji KBM (Konsentrasi Bunuh Minimum) dianalisis menggunakan Kolmogrov-smirnov, kemudian dilanjutkan dengan uji korelasi pearson. Hasil uji normalitas menunjukkan bahwa ekstrak dan fraksi A.manihot memiliki nilai signifikan terdistribusi normal $(\mathrm{p}>0,05)$. Analisis korelasi pearson ekstrak dan fraksi A.manihot dengan aktivitas antibakteri terhadap E.coli menunjukkan hasil signifikan (p <0,05). $71 \%$ aktivitas antibakteri dipengaruhi oleh fenolik total dan sisanya merupakan kontribusi senyawa lain yang berpotensi sebagai antibakteri.
\end{abstract}

Kata kunci : Fenol Total, Korelasi, Escherichia coli, Gedi Hijau 


\section{PENDAHULUAN}

Abelmoschus manihot L. atau yang dikenal dengan nama daerah gedi adalah salah satu tumbuhan dari suku Malvaceae. Daun gedi mudah tumbuh dengan cara stek batang pada tanah gembur. Di Sulawesi Utara masyarakat mengenal dua jenis Abelmoschus manihot L. yaitu gedi merah dan gedi hijau. Daun gedi hijau dapat dimanfaatkan oleh masyarakat Manado sebagai bahan makanan yang dikenal sebagai Bubur Manado (Tinutuan), sedangkan untuk daun gedi merah digunakan masyarakat untuk mengobati penyakit(Mamahit dan Soekarno, 2010).

Senyawa Fenolik adalah senyawa senyawa yang memiliki gugus hidroksil yang menempel pada cincin aromatik (Vermerris dan Nicholson, 2006). Fenol telah dipelajari secara ekstensif sebagai desinfektan yang mempunyai aktivitas antibakteri berspektrum luas terhadap bakteri Gram positif dan Gram negative. Dalam konsentrasi tinggi, kandungan fenol menembus dan mengganggu dinding sel bakteri dan mempresipitasi protein dalam sel bakteri. Dalam konsentrasi yang lebih rendah, fenol menginaktifkan sistem enzim penting dalam sel bakteri (Oliver dkk, 2001). Jain dan Bari (2010) menyatakan bahwa batang dan tanaman gedi memiliki aktivitas anti-inflamatori dan antibakteri.

Salah satu cara pengendalian terhadap Escherichia coli dapat menggunakan tanaman yang memiliki kandungan kimia alami sebagai antibakteri sehingga di harapkan dapat menghambat pertumbuhan bakteri E.coli (Sutarmi S,1993).

Berdasarkan perihal di atas untuk mengoptimalkan tanaman Indonesia sebagai antibakteri, maka penulis tertarik untuk melakukan penelitian yang berjudul analisis korelasi antara kandungan fenol total dengan aktivitas antibakteri ekstrak dan fraksi Abelmoschus manihot L. terhadap Escherichia coli.

\section{METODOLOGI PENELITIAN}

\section{Alat dan Bahan}

a. Alat

Alat-alat ukur analitis yang digunakan untuk penelitian ini ialah spektrofotometer uv-vis (Shimadzu 00780), Komputer pengolah data (Acer Aspie ES 11), Alat-alat gelas, Vortex (Mixer Hwashin), Autoklaf , Inkubator (Ecocell), Alumunium Foil, Mikropipet, Neraca analitik, Waterbath (Julabo), Corong pisah, LAF, Blender (Philips).

b. Bahan

Bahan utama yang digunakan dalam penelitian ini adalah daun gedi dari MITRA, dan Bahan-bahan lain yang digunakan antara lain : N-Heksana teknis, Etil asetat teknis, Etanol teknis, Nutrien Broth, Aquades, Escherichia coli yang diperoleh dari Laboratorium Farmasi Unsrat, Asam galat, Nutrient Broth (NB), Nutrient Agar (NA), Antibiotik Ciprofloxacin (Merk Ciprofloxacin), Larutan standar McFarland, $\mathrm{NaCl}$ 0,9\%, DMSO 10\%, Follin ciocalteu, Natrium karbonat.

\section{Ekstraksi}

Sebanyak 250 g simplisia dimasukkan ke dalam wadah toples dan kemudian ditambahkan etanol 96\%. Ekstraksi dilakukan dengan cara maserasi selama 3 hari dengan beberapa kali pengocokan. Ekstrak hasil maserasi kemudian dipekatkan 
dengan rotary evaporator hingga terbentuk ekstrak kental.

\section{Fraksinasi}

Sebanyak 10 g ekstrak etanol Abelmoschus manihot L. dimasukkan kedalam Erlenmeyer dan dilarutkan dengan pelarut etanol sebanyak $100 \mathrm{~mL}$. Setelah sampel larut, sampel dimasukan ke dalam corong pisah dan ditambahkan pelarut nheksan sebanyak $100 \mathrm{~mL}$. Sampel kemudian dikocok dalam corong pisah hingga homogen. Sampel dibiarkan selama 10-15 menit hingga terdapat dua lapisan air (air pada lapisan bawah dan n-heksan pada lapisan atas). Masing-masing kedua lapisan air dan n-heksan ditampung dalam wadah yang berbeda. Lapisan n-heksan selanjutnya dievaporasi menggunakan rotary evaporator hingga kering lalu ditimbang dengan timbangan analitik dan diperoleh fraksinat. Perlakuan yang sama terhadap pelarut etil asetat dan etanol.

\section{Dilusi}

Metode dilusi cair dilakukan dengan menyiapkan beberapa tabung reaksi yang sudah steril, larutan uji dan bakteri uji sebagai control negative, larutan antibiotic pembanding (Ciprofloxacin) dan bakteri uji sebagai control positif. Selanjutnya tiap-tiap tabung diisi dengan 1,4 $\mathrm{mL}$ medium Nutrient Broth. Selanjutnya ditambahkan 0,5 mL larutan uji pada tabung reaksi di vortex. Kemudian masing-masing tabung ditambahkan 0,1 mL suspensi bakteri e.coli dan di vortex. Sebelum diinkubasi, setiap tabung dilusi diamati seksama dan diukur absorbansi pada spektrofotometer UV-VIS panjang gelombang $600 \mathrm{~nm}$. Kemudian seluruh tabung diinkubasi pada suhu $37^{\circ} \mathrm{C}$ selama 24 jam. Setelah inkubasi, setiap tabung dilusi diamati seksama dan diukur absorbansi kembali pada spektrofotometer UV-VIS pada panjang gelombang $600 \mathrm{~nm}$. Dibandingkan hasil pengamatan kekeruhan antara sebelum dan sesudah inkubasi serta dibandingkan nilai absorbansi sebelum dan sesudah inkubasi, bertambahnya nilai absorbansi setelah inkubasi menunjukan adanya pertumbuhan sel bakteri yang hidup, sedangkan konstan dan berkurangnya nilai absorbansi setelah inkubasi menunjukan tidak adanya pertumbuhan sel bakteri yang hidup sehingga dapat disimpulkan titik konsentrasi ini adalah KHM (Konsentrasi Hambat Minimal) yang dapat menghambat pertumbuhan. Selanjutnya untuk membuktikan apakah sampel memiliki kemampuan membunuh, maka dilakukan penentuan KBM (Konsentrasi Bunuh Minimal) yaitu dengan mengambil 1 ose dari masing-masing tabung kemudian diinokulasi pada media Nutrient Agar dalam cawan petri dan diinkubasi selama 24 jam pada suhu $37^{\circ} \mathrm{C}$. Replikasi dilakukan sebanyak 3 kali. Setelah 24 jam diamati adanya pertumbuhan bakteri berarti sampel bersifat bakteriostatik, sedangkan apabila tidak ada pertumbuhan bakteri berarti sampel bersifat bakterisidal.

\section{Penentuan Kandungan Fenol Total} Ekstrak dan Fraksi Abelmoschus manihot L.

a. Penentuan Operating Time

Sebanyak $300 \mu \mathrm{L}$ larutan asam galat konsentrasi $30 \mu \mathrm{g} / \mathrm{mL}$ ditambah $1,5 \quad \mathrm{~mL}$ reagen Folin Ciocalteu $25 \%$, kemudian digojog dan didiamkan selama 3 menit. $\mathrm{Ke}$ 
dalam larutan tersebut ditambahkan $1,2 \mathrm{~mL}$ larutan Natrium Karbonat $\left(\mathrm{Na}_{2} \mathrm{CO}_{3}\right) 5 \%$, digojog homogen, dan diukur absorbansinya dalam rentang waktu $0-90$ menit pada panjang gelombang $750 \mathrm{~nm}$ (Thesalonika dkk, 2018).

b. Penentuan panjang gelombang absorbansi maksimum

Sebanyak $300 \mu \mathrm{L}$ larutan asam galat konsentrasi $30 \mu \mathrm{g} / \mathrm{mL}$ ditambah $1,5 \mathrm{~mL}$ reagen Folin-Ciocalteau $25 \%$, kemudian digojog dan didiamkan selama 3 menit. Ke dalam larutan tersebut ditambah $1,2 \mathrm{~mL}$ larutan Natrium karbonat $5 \%$, digojog homogen, dan didiamkan pada suhu kamar pada range operating time, kemudian absorbansinya diukur pada panjang gelombang 700-800 nm (Thesalonika dkk, 2018).

c. Pembuatan kurva baku asam galat

Sebanyak $300 \mu \mathrm{L}$ larutan asam galat konsentrasi 20, 30, 40, 50, dan $60 \mu \mathrm{g} / \mathrm{mL}$ masing-masing dimasukkan ke dalam tabung, kemudian ditambah $1,5 \mathrm{~mL}$ reagen Folin Ciocalteau $25 \%$ dan digojog. Setelah didiamkan selama 3 menit, masing-masing larutan ditambah $1,2 \mathrm{~mL}$ larutan Natrium Karbonat $2 \%$, digojog homogen dan didiamkan pada range operating time pada suhu kamar. Semua larutan diukur absorbansinya pada panjang gelombang absorbansi maksimum, kemudian di buat kurva kalibrasi hubungan antara konsentrasi asam galat $(\mu \mathrm{g} / \mathrm{mL})$ dengan absorbansi (Thesalonika termodifikasi, 2019).

d. Penentuan kandungan total fenolik ekstrak daun gedi hijau
Sebanyak 10,0 mg fraksi dari masingmasing fraksi daun gedi hijau dilarutkan sampai volume $10,0 \mathrm{~mL}$ akuades. Larutan fraksi yang diperoleh dipipet sebanyak 300 $\mu \mathrm{L}$, dan ditambah reagen $1,5 \mathrm{~mL}$ FolinCiocalteau $25 \%$ dan digojog, didiamkan selama 3 menit, ditambah $1,2 \mathrm{~mL}$ pelarut Natrium Karbonat $\left(\mathrm{Na}_{2} \mathrm{CO}_{3}\right) \quad 5 \%$ dan didiamkan lagi pada range operating time pada suhu kamar. Absorbansi ekstrak diukur pada panjang gelombang maksimum. Perhitungan kandungan fenolik total menggunakan rumus berikut:

$$
\mathrm{TPC}=\frac{c . v \cdot f p}{g}
$$

Keterangan:

$\mathrm{c}=$ konsentrasi fenolik (nilai $\mathrm{x}$ )

$\mathrm{v}=$ volume ekstrak yang digunakan

$(\mathrm{mL})$

$\mathrm{fp}=$ faktor pengenceran

$\mathrm{g}=$ berat sampel yang digunakan $(\mathrm{g})$

\section{HASIL DAN PEMBAHASAN \\ Ekstraksi dan Fraksinasi}

Sebanyak 250 gram daun gedi hijau maka diketahui jumlah rendemen dari Minahasa Tenggara sebesar 7,23\%. Proses fraksinasi pada penelitian ini dilakukan dengan metode partisi dengan alat yang digunakan adalah alat yang sederhana yaitu corong pisah maka diketahui jumlah rendemen masing-masing fraksi n-heksan sebesar 8,42 \%, fraksi etil asetat sebesar $15,12 \%$, dan fraksi etanol sebesar $32,47 \%$.

\section{Operating time}

Berdasarkan hasil pengukuran yang diperoleh, absorbansi yang stabil pada menit ke-30 sehingga dapat disimpulkan Operating time untuk penetapan kandungan total fenolik ekstrak daun gedi hijau adalah 
30 menit. Penetapan Operating time bertujuan untuk mendapatkan waktu pengukuran pada saat reaksi telah berjalan optimal yang ditandai dari absorbansi yang stabil, sehingga dapat memaksimalkan pengukuran (Pangestuty, 2016).

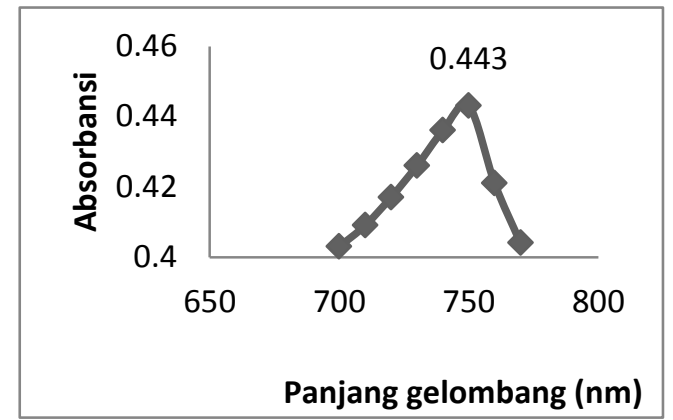

\section{Gambar 1. Panjang Gelombang Maksimum}

Hasil panjang gelombang maksimum pada konsentrasi $30 \mu \mathrm{g} / \mathrm{mL}$ asam galat diperoleh panjang gelombang maksimum $750 \mathrm{~nm}$ dengan hasil absorbansi 0,443.

\section{Penentuan Kurva Baku dan Linearitas}

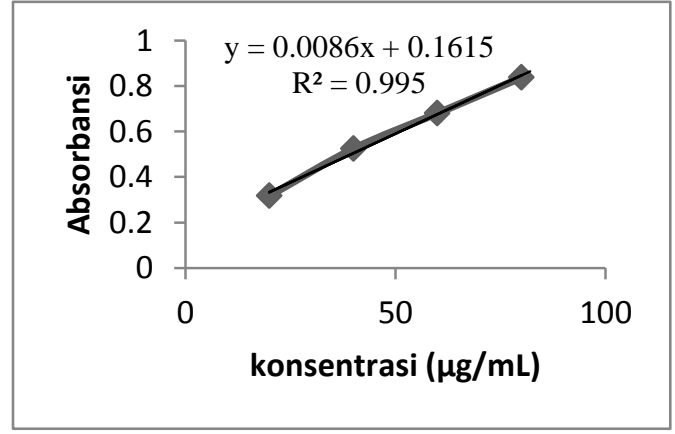

Hasil pengukuran persamaan regresi linear dari kurva kalibrasi yang diperoleh adalah $\mathrm{y}=0.0086 \mathrm{x}+0.1615$ dengan koefisien korelasi $\mathrm{R}^{2}=0.995$. persamaan kurva kalibrasi merupakan hubungan antara sumbu x dan sumbu y. sumbu $x$ dinyatakan dengan konsentrasi yang diperoleh sedangkan sumbu y merupakan absorbansi atau serapan yang diperoleh. Harga koefisien korelasi menyatakan hubungan yang linier antara konsentrasi dengan serapan yang dihasilkan. Berdasarkan hasil $r^{2}$ yang diperoleh bahwa koefisien korelasi memberikan hasil yang linear karena memenuhi kriteria yang dapat diterima yaitu 0,99 (Miller, 2005).

Penentuan Kandungan Total Fenolik Ekstrak dan Fraksi Daun Gedi Hijau

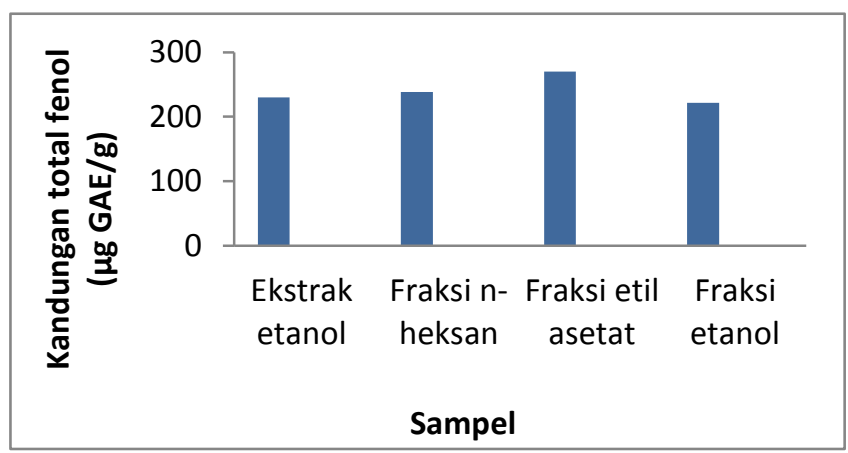

Perhitungan kandungan total fenolik yang diperoleh dari masing-masing ekstrak dan fraksi daun gedi hijau menunjukkan bahwa fraksi etil asetat memiliki nilai absorbansi tertinggi yaitu 269,77 $\mu \mathrm{g} \mathrm{GAE/g;}$ fraksi n-heksan yaitu 238,37 $\mu \mathrm{g}$ GAE/g; dan ekstrak etanol yaitu 230,23 $\mu \mathrm{g}$ GAE/g dan terkecil fraksi etanol yaitu 221,51 $\mu \mathrm{g} \mathrm{GAE} / \mathrm{g}$ - Berdasarkan hasil yang diperoleh, membuktikan bahwa pelarut etil asetat paling efektif dalam mengikat senyawa aktif yang terdapat pada ekstrak daun Abelmoschus manihot L. dan senyawa yang terkandung dalam gedi lebih mudah larut dalam pelarut etil asetat.

\section{Uji Aktivitas Antibakteri}

Hasil perhitungan nilai $\Delta \mathrm{OD}$, nilai negative $\Delta \mathrm{OD}$ yang terkecil yaitu fraksi etil 
asetat yaitu sebesar -0.029 , fraksi n-heksan sebesar -0.155 , dan untuk nilai positif yaitu pada ekstrak etanol sebesar 0.082 yang terletak pada konsentrasi $1000 \mu \mathrm{g} / \mathrm{mL}$ dan pada fraksi etanol sebesar 0.097. Ini menunjukkan bahwa terjadi penurunan nilai OD sebelum inkubasi dan sesudah inkubasi pada setiap perlakuan yang telah diberi ekstrak dan fraksi daun Abelmoschus manihot L. dan pada perlakuan control positif dibandingkan dengan perlakuan control negative. Dalam perlakuan control negative tanpa pemberian ekstrak dan fraksi Abelmoschus manihot L. mengalami peningkatan nilai OD artinya pada perlakuan control negative terjadi peningkatan pertumbuhan bakteri E.coli.

Hasil pengujian MBC (Konsentrasi bunuh minimum) menunjukkan bahwa jumlah rata-rata koloni paling banyak terdapat pada perlakuan control negative (tanpa pemberian ekstrak Abelmoschus manihot L.) yaitu sebanyak 334 koloni sedangkan jumlah rata-rata koloni paling sedikit terdapat pada konsentrasi 1000 $\mu \mathrm{g} / \mathrm{mL}$ dan control positif yaitu sebanyak 0 koloni. Penurunan jumlah koloni bakteri ini dikarenakan pada konsentrasi yang semakin tinggi mengandung senyawa antibakteri yang lebih banyak sehingga semakin banyak senyawa ajyntibakteri yang diserap koloni bakteri dan menyebabkan pertumbuhan koloni bakteri menjadi terhambat (Noorhamdani et al, 2011).

\section{Korelasi Antara Kandungan Fenol Total dengan Aktivitas Antibakteri}

Hasil data uji kbm dianalisis dengan uji Kolmogrov - smirnov, dan dilanjutkan dengan uji Korelasi Pearson serta uji Regresi
Linier Sederhana. Uji kolmogrov smirnov data hasil uji KBM ekstrak dan fraksi Abelmoschus manihot L bertujuan untuk mengetahui apakah nilai residual berdistribusi normal atau tidak. Model regresi yang baik adalah memiliki nilai residual yang berdistribusi normal jika nilai signifikasi > 0,05. Hasil uji kolmogrov smirnov yaitu ekstrak etanol sebesar 0,761, fraksi n-heksan sebesar 0,287, fraksi etil asetat sebesar 0,547, fraksi etanol sebesar 0,569 memiliki nilai signifikasi > 0,05 yang berarti nilai residual berdistribusi normal . Hal ini berarti data hasil uji KBM yang ditunjukkan dengan jumlah pertumbuhan koloni bakteri E.coli pada setiap perlakuan signifikan normal sehingga dapat dilanjutkan dengan uji Korelasi Pearson dengan taraf kepercayaan 5\%. Hasil uji korelasi pearson menunjukkan nilai korelasi terbesar yaitu fraksi etil asetat signifikasi yaitu 0,003 ( $\mathrm{p}<0.05)$, fraksi n-heksan signifikansi 0,004 ( $\mathrm{p}<0,05)$, ekstrak etanol signifikansi $0,006(\mathrm{p}<0,05)$, fraksi etanol signifikasi 0,009 yang berarti terdapat hubungan antara peningkatan konsentrasi ekstrak dan fraksi Abelmoschus manihot L. dengan penurunan jumlah koloni E.coli. Besar koefisien korelasi pearson antara konsentrasi dengan jumlah koloni bakteri yaitu ekstrak etanol sebesar $\mathrm{R}=-0,673$, fraksi $n$-heksan sebesar $R=-0,695$, fraksi etil asetat sebesar $\mathrm{R}=-0,714$, fraksi etanol sebesar $R=-0,651$. Tanda negative menunjukkan hubungan yang terbalik yang berarti semakin tinggi konsentrasi ekstrak Abelmoschus manihot L. yang diberikan maka semakin sedikit jumlah koloni bakteri E.coli yang tumbuh. Dengan kata lain semakin besar kandungan fenolik totalnya, 
semakin tinggi aktivitas antibakterinya. Berdasarkan hasil korelasi pearson diketahui bahwa nilai korelasi Fraksi n-heksan sebesar 0,695 yang berarti bahwa peran kontribusi senyawa fenolik terhadap aktivitas antibakteri sebesar $69 \%$, Fraksi etil asetat sebesar 0,714 yang berarti bahwa peran kontribusi senyawa fenolik terhadap aktivitas antibakteri sebesar $71 \%$, Ekstrak etanol sebesar 0,673 yang berarti peran kontribusi senyawa fenolik terhadap aktivitas antibakteri sebesar $67 \%$ Fraksi etanol sebesar 0,651 yang berarti bahwa peran kontribusi senyawa fenolik terhadap aktivitas antibakteri sebesar $65 \%$. Hal ini membuktikkan bahwa kandungan fenol total ekstrak dan fraksi Abelmoschus manihot $\mathrm{L}$. memiliki aktivitas antibakteri. Menurut Pelczar dan Chan (2008), menyatakan bahwa fenol bekerja melalui koagulasi protein dan perusak membrane sel. Persenyawaan fenol dapat bersifat bakteriosidal dan bakteriostatis tergantung dengan konsentrasi yang digunakan. Berdasarkan hasil yang diperoleh menunjukkan bahwa fraksi etil asetat menunjukkan hasil terbaik, hal ini diduga etil asetat memiliki sifat hidrofilik dan lipofilik sehingga polaritas menjadi optimum dan zat antimikroba yang diperoleh menjadi maksimal (Harborne, 1987).

\section{KESIMPULAN}

1. Kandungan fenolik total ekstrak dan fraksi Abelmoschus manihot $\mathrm{L}$. memperoleh hasil untuk ekstrak etanol sebesar 230,23 $\pm 0,008 \mu \mathrm{g} \mathrm{GAE} / \mathrm{g}$, fraksi n-heksan sebesar 238,37 $\pm 0,024 \mu \mathrm{g}$ $\mathrm{GAE} / \mathrm{g}$, fraksi etil asetat sebesar 269,77 \pm
$0,016 \mu \mathrm{g} \mathrm{GAE} / \mathrm{g}$ dan fraksi etanol sebesar $221,51 \pm 0,001 \mu \mathrm{g} \mathrm{GAE} / \mathrm{g}$.

2. Berdasarkan hasil uji dilusi menunjukkan bahwa jumlah rata-rata koloni paling sedikit terdapat pada fraksi etil asetat pada konsentrasi $1000 \mu \mathrm{g} / \mathrm{mL}$.

3. Korelasi antara aktivitas antibakteri dengan kandungan fenol total ekstrak dan fraksi Abelmoschus manihot L. terhadap Echerichia coli menunjukkan hasil uji kolmogrov smirnov data hasil uji kbm memiliki nilai signifikasi terdistribusi normal atau ( $>0.05)$ yang berarti signifikan dan dapat dilanjutkan dengan uji Korelasi Pearson dengan taraf kepercayaan 5\% dan memperoleh hasil signifikan 0,003 ( $\mathrm{p}<0,05)$. Kandungan fenolik total mempengaruhi besarnya aktivitas antibakteri yaitu ekstrak etanol sebesar $67 \%$ aktivitas antibakteri dipengaruhi oleh fenolik total, fraksi nheksan sebesar $69 \%$ aktivitas antibakteri dipengaruhi oleh fenolik total, fraksi etil asetat sebesar $71 \%$ aktivitas antibakteri dipengaruhi oleh fenolik total, dan fraksi etanol sebesar $65 \%$ aktivitas antibakteri dipengaruhi fenolik total.

\section{SARAN}

Disarankan untuk melakukan penelitian lebih lanjut tentang korelasi antara kandungan total fenol ekstrak dan fraksi daun gedi hijau (Abelmoschus manihot L.). terhadap bakteri yang lain.

\section{DAFTAR PUSTAKA}

Harborne, J.B. 2006. Metode Fitokimia: Penuntun Cara Modern Menganalisis Tumbuhan. ITB Press, Bandung 
Jain, P. S., S. B. Bari. 2010. Antiinflammatory Activity of Abelmoschus manihot Extracts. International Journal of Pharmacology. 6(4):505-509

Mamahit L.P. Soekarno,N.H., 2010. Satu Senyawa Organic yang Diisolasidari Daun Gedi (Albemoschus manihot L. Medik) Asal Sulawesi Utara. Chemistry Progress, 3(1) : 45.

Noorhamdani, A. S., Chielwin, I. G. 2010. Uji Efektivitas Antibakteri Ekstrak Etanol Bawang Putih (Allium sativum) Terhadap Pertumbuhan Streptoccocus mutans Penyebab Karies Secara In Vitro. Universitas Brawijaya, Malang

Oliver, S. P., B. E. Gillespie, M. J. Lewis, S. J. Ivey, R. A. Almeida, D. A. Luther, D. L. Johnson, K. C. Lamar, H. D. Moorehead and H. H.Dowlen. 2001. Efficacy Of A New Premilking Teat Disinfectant Containing A Phenolic Combination For The Prevention Of Mastitis. J. Dairy Sci. 84 (3) : 15451549.

Pangestuty, A. 2016. Uji Aktivitas Antioksidan dan Penentapan Kadar
Fenolik Total Fraksi Etil Asetat Ekstrak Buah Buni dengan Metode 2,2-Difenil-1-Pikrilhidrazil (DPPH) dan Metode Folin-Ciocalteu [skripsi]. Fakultas Farmasi, Universitas Sanata Dharma, Yogyakarta.

Pelczar, M. J., Chan, E. C. S., 2008. DasarDasar Mikrobiologi 2. UI Press, Jakarta

Rohman, A. 2007. Kimia Farmasi Analisis. Pustaka Pelajar, Yogyakarta

Sutarmi, S. 1993. Botani Umum. Angkasa Bandung, Bandung

Thesalonika, G. A., Sudewi, S., Rorong, J. A. 2018. Optimasi dan Validasi Metode Analisis dalam Penentuan Kandungan Total Fenolik pada Ekstrak Daun Gedi Hijau (Abelmoschus manihot L.) yang Diukur dengan Spektrofotometer UV-Vis. Jurnal Ilmiah Farmasi.7(3) : 14-21

Vermerris, W. and Nicholson, R. 2006. Phenolic Compound Biochemistry, Springer, The Netherlands. 